\title{
Commentary
}

CrossMark

\& clickfor update

\section{Learning from Past Experiences in Controlling the Spread of the SARS-CoV-2 Pandemic}

\section{Daniel Kerr Baines}

\author{
The Lancaster University, Lancaster, United Kingdom
}

\begin{abstract}
Received |February 05, 2020; Accepted | February 23, 2020; Published | February 28, 2020
*Correspondence | Daniel Kerr Baines, The Lancaster University, United Kingdom; Email: d.k.baines@lancaster.ac.uk

DOI | http://dx.doi.org/10.17582/journal.hv/2020/7.1.7.9

Citation | Baines, D.K. 2020. Learning from past experiences in controlling the spread of the SARS-CoV-2 pandemic. Hosts and Viruses, 7(1): 7-9.
\end{abstract}

Keywords: SARS-CoV-2, Pandemic, Disease, Epidemic

\begin{abstract}
A t the time of writing this article 11 April 2020, the disease CoVID-19 caused by the virus $S A R S-C o V-2$ has claimed over 100,000 lives and affected essentially every country on the globe with over 1.6 million cases (John Hopkins, 2020). CoVID-19 has overwhelmed the medical capacity of countries like Italy and Spain, to a point not seen since the Spanish flu epidemic. Ports and countries are closed, people are on lock down, people are dying due to a lack of medical supplies and the world seems on the verge of collapse; not just medically but also socially and economically.
\end{abstract}

\section{Are we really doing enough to tackle this problem?}

Like it or not we now live in a global society. The raw materials for drugs taken daily, by people, without a thought, worldwide, come from places like China and India. The raw materials are then mixed into the various medications into bulk powders. This happens in other countries such as the United Kingdom before being further shipped to places like Italy to be pressed into tablet form or packaged. Respiratory equipment, arguably one of the most vital pieces of equipment present in today's pandemic, are majorly produced in Ecuador. These supplies are needed worldwide, and we are reliant on global transport. Not just medical supplies either but food or everyday modern day non-essentials too. Mitigated properly this distribution doesn't needs be halted. Furthermore, it could possibly help curb the spread of the Covid-19 disease and possibly mitigate any unnecessary strains on the world's economy. Could this be achieved by implementing measures used in the Serotype O Pan Asia Foot and Mouth disease outbreak?

This isn't the first global pandemic we have faced as a population, neither is it likely to be the last. In 2001 the globe was hit with a pandemic in the form of a hyper virulent strain of an airborne virus belonging to the Picornaviridae family, Serotype O Pan Asia Foot and Mouth Virus. The mutant strain of the already known virus swept out of Asia in 1998 into Africa, before wreaking havoc between 2000 and 2001 in Korea, Russia, Japan, France, the Netherlands, the United Kingdom and Ireland (Knowles et al., 2005). The disease caused acute vesicular disease on the feet and mouths of the affected animals (Salguero et al., 2005). The virus killed both wild and domesticated animals decimating pigs, cattle, sheep, goats, water buffalo and various other Bovidae. (Dekker, 2019). The United kingdom alone lost over 6 million cows and sheep either through the disease or the culling of livestock to stop the spreading, depleting the viral load (KnightJones and Rushton, 2013). Costing at the time to the economy was around $£ 3.1$ billion (Thompson et al., 2002), although other estimates are closer to $£ 8$ billion (Knight-Jones and Rushton, 2013). 
As with the $S A R S-C o V-2$ virus, various measures were put in place to mitigate the spread of the virus. However, due to the differing natures of the viruses the measures were different. Can these methods be utilised in this current pandemic? These measures ensured the global movement of essential goods. Firstly, all lorries leaving or returning to ports or boarders were sprayed with iodine based disinfectants and drove through similar solutions. Every person of a certain age in the United Kingdom will remember driving through similar iodine based solutions. Granted we are discussing two different types of viruses; both with differing mechanism of cell entry and attacking different tissues. Although, both are single stranded RNA virus (Cascella et al., 2020) (Grubman and Baxt, 2004), but are from different families; SARS-CoV-2 (Coronaviridae), Serotype O Pan Asia Foot and Mouth Virus (Picornaviridae). Other Coronaviridae have been shown to be susceptible to alcohol based disinfectants.

A Guardian article by (Renwick, 2020) on the 25th March highlighted an investigation carried out on the Princess Cruise Ship by DR Julia Marcus and Dr Akiko Iwasaki. They found $S A R S-C o V-2$ RNA present 17 days after the passengers had left. Although, they stated that it was purely the virus's RNA remaining and this has no infectious potential. Furthermore, $S A R S-C o V-2$ has been detected on various surfaces acting as fomites surviving in aerosols for 3 hours, 4 hours on copper, 1 day on cardboard, and between 3 and 4 days on plastic and stainless steel, respectively (van Doremalen et al., 2020).

Bringing all this information together highlights the potential that an infected individual's car has the potential to become a fomite. Even if the infected person has no contact with the tyres for example, rain or even morning dew would suffice to translocating the virus onto the road, maybe into a puddle, then becoming a reservoir for the virus. As is well established by now, $S A R-C o V-2$ can survive within water droplets. The aim of the 2-metre social distancing is to allow for the increased chance that water vapour from an infected individual's breath will fall to the floor before reaching the next individual. If a car has the potential to be a fomite and any driver will be aware of the spray produced from the vehicles on the roads, and as established $S A R-C o V-2$ virus is transmitted through water droplets.

Implementing road disinfectants could help to mit- igate the risk of the further spread of the Covid-19 disease. The same with the correct, mass disinfection of the vehicles returning and leaving ports or boarders, with the use of disinfection pads for example. The type of disinfection that was employed during the Serotype O Pan Asia Foot and Mouth outbreak would allow for the movement of essentials and technically what could be classed as now non-essential goods. This would theoretically allow the world to continue moving and supplying, mitigating the impending economic downfall once the Covid-19 peak has passed and settled.

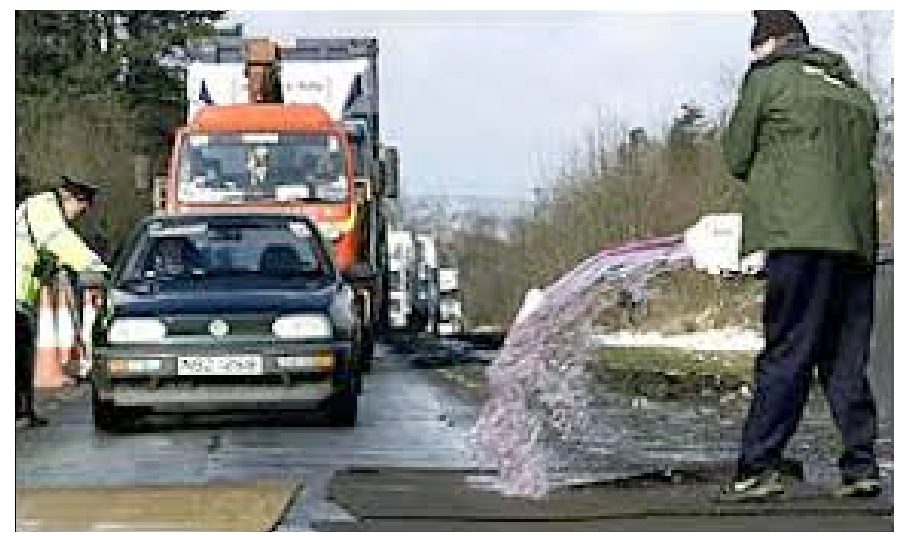

BBC (2001) What's the point in foot and mouth mats. Available at: http://news.bbc.co.uk/1/hi/ $\mathrm{uk} / 1270148 . \mathrm{stm}$

\section{References}

Cascella, M., Rajnik, M., Cuomo, A., Dulebohn, S. C. \& Di Napoli, R. 2020. Features, Evaluation and Treatment Coronavirus (COVID-19). StatPearls. Treasure Island (FL).

Dekker, D. A. 2019. Foot-and-mouth-disease.

GRUBMAN, M. J. \& BAXT, B. 2004. Foot-andmouth disease. Clin Microbiol Rev, 17, 465-93.

Knight-Jones, T.J. \& Rushton,J.2013. The economic impacts of foot and mouth disease - what are they, how big are they and where do they occur? Prev Vet Med, 112, 161-73.

Knowles, N. J., Samuel, A. R., Davies, P. R., Midgley, R. J. \& Valarcher, J. F. 2005. Pandemic strain of foot-and-mouth disease virus serotype $\mathrm{O}$. Emerg Infect Dis, 11, 1887-93.

Md, R. E. 2020. Covid-19 Nejm Journal Coverage Renwick, D. 2020. How long doe coronavirus last survive on different surface? The Guardian, 25th March.

Salguero, F. J., Sanchez-Martin, M. A., Diaz-San Segundo, F., De Avila, A. \& Sevilla, N. 2005. 
Foot-and-mouth disease virus (FMDV) causes an acute disease that can be lethal for adult laboratory mice. Virology, 332, 384-96.

Thompson, D., Muriel, P., Russell, D., Osborne, P., Bromley, A., Rowland, M., Creigh-Tyte, S. \& Brown, C. 2002. Economic costs of the foot and mouth disease outbreak in the United Kingdom in 2001. Rev Sci Tech, 21, 675-87.

Van Doremalen, N., Bushmaker, T., Morris, D. H., Holbrook, M. G., Gamble, A., Williamson, B. N., Tamin, A., Harcourt, J. L., Thornburg, N. J., Gerber, S. I., Lloyd-Smith, J. O., De Wit, E. \& Munster, V.J. 2020. Aerosol and Surface Stability of SARS-CoV-2 as Compared with SARS$\mathrm{CoV}-1 . \mathrm{NEnglJ}$ Med.

John Hopkins University 'Interactive live coronavirus map.' Available at; https://coronavirus.jhu. edu/map.html 